Małgorzata Pakier

\title{
Prehistoria pamięci. Zagłada we wczesnym amerykańskim programie rozrywkowym ${ }^{1}$
}

W latach 1952-1961 amerykańska telewizja NBC regularnie emitowała półgodzinny talk-show This Is Your Life! Prowadzący program Ralph Edwards zapraszał do studia zarówno osoby znane publicznie, jak i nieznanych bohaterów życia codziennego. Osoby te były z zaskoczenia wyławiane spośród widowni zgromadzonej w telewizyjnym studiu i zapraszane na scenę. W dalszej części programu ich historia była opowiadana widzom przed telewizorami. Wśród odcinków tego popularnego programu, wznawianego również w następnych dekadach, znajdujemy historie życia wielu większych i mniejszych sław ze świata amerykańskiego show-biznesu, filmu, muzyki czy sportu. Kilkakrotnie na bohaterów programu wybrani zostali także tzw. świadkowie historii. W programie z 27 maja 1953 r. opowiedziano historię Hanny Bloch Kohner - ocalałej z Zagłady czechosłowackiej Żydówki, która po wojnie przybyła do Ameryki i poślubiła hollywoodzkiego producenta. Odcinek This Is Your Life! z Hanną Bloch Kohner to prawdopodobnie pierwszy po wojnie przypadek wykorzystania tematu Zagłady w telewizyjnym programie rozrywkowym.

W ostatnich latach zaczęto zwracać większą uwagę na rolę masowych mediów w kształtowaniu pamięci Zagłady, dostrzegając zasługi popularnych przedstawień w przekazywaniu wiedzy o zbrodniach drugiej wojny światowej szerszej rzeszy odbiorców ${ }^{2}$. Wiele napisano o roli, jaką serial Holocaust odegrał u schyłku

\footnotetext{
${ }^{1}$ Artykuł ten powstał dzięki stypendium fundacji Charles H. Revson uzyskanym na badania w Center for Advanced Holocaust Studies, United States Holocaust Memorial Museum w Waszyngtonie.

${ }^{2}$ Zob. między innymi: Miriam Bratu Hansen, Schindler’s List is not Shoah. The Second Commandment, Popular Modernism, and Public Memory, „Critical Inquiry”, zima 1996, s. 292-312; Bilder des Holocaust. Literatur - Film - Bildende Kunst, red. Manuel Köppen, Klaus R. Scherpe, Köln: Böhlau, 1997; Alan Mintz, Popular Culture and the Shaping of Holocaust Memory in America, Seattle: University of Washington Press, 2001; Visual Culture and the Holocaust, red. Barbie Zelizer, New Brunswick, NJ: Rutgers University Press, 2001; Alison Landsberg, Prosthetic Memory: The Transformation of American Remembrance in the Age of Mass Culture, New York: Columbia University Press, 2004.
} 
lat siedemdziesiątych ubiegłego wieku w zachodnich Niemczech ${ }^{3}$. To ten serial telewizyjny, oglądany w prywatnej przestrzeni domu i opowiadający historię Zagłady w sfabularyzowany sposób i z perspektywy losów pojedynczych bohaterów, stworzył możliwość empatycznej identyfikacji z ofiarami i znacząco wpłynął na kształt społecznej świadomości Zagłady w RFN. Kilka lat temu Daniel Levy i Natan Szneider proklamowali natomiast pojawienie się etycznej wspólnoty pamięci już na poziomie globalnym. Jej zawiązaniu miałyby sprzyjać popularne reprezentacje Zagłady, rozpowszechniane coraz częściej za sprawą masowych mediów. Kultura masowa, którą autorzy nazwali „frywolnym przemysłem” i „pogańskim rytuałem afirmacji życia”, ma ich zdaniem „demokratyzować” pamięć Zagłady, wydzierając ją wąskim elitom, które roszczą sobie prawo do wyłączności na określanie uprawnionych sposobów przedstawiania ${ }^{4}$. Refleksja nad Zagładą i możliwościami jej prezentowania przeszła już długą drogę od powojennych pesymistycznych pytań Theodora Adorno o kulturę po Auschwitz przez dyskusje wokół Shoah Claude’a Lanzmanna aż do tezy o „globalnej wspólnocie pamięci”. Odcinek programu This Is Your Life! z Hanną Bloch Kohner w roli głównej jest zapisem momentu historycznego, w którym społeczne ramy pamięci Zagłady nie są jeszcze zdefiniowane, a szczególna relacja między kulturą masową, pamięcią publiczną i Zagładą dopiero zaczyna się kształtować. Tym wyraźniej jawi się w tym programie napięcie między jednostkowym doświadczeniem historii a wymogiem takiej opowieści, która dotrze do serc szerokiej rzeszy odbiorców kultury.

\section{Początki gatunku}

Gatunek telewizyjnego talk-show w latach pięćdziesiątych dopiero zaczynał się formować. Na omawiany odcinek This Is Your Life! z 1953 r. spoglądamy dziś więc $\mathrm{z}$ lekkim rozbawieniem. Zwraca uwagę prymitywny mikrofon $\mathrm{w}$ rękach prowadzącego, tandetne elementy dekoracji, a także mało płynne z dzisiejszej perspektywy ruchy kamery i montaż. Choć wszystko odbywa się według scenariusza, ruch na scenie jest dość nieporadny, a postaciom brak spontaniczności i oswojenia z kamerą. Odnajdujemy jednak w tym programie również liczne cechy stale charakteryzujące współczesne talk-show. Programy tego typu odwołują się do popularnych form dramatycznych, łącząc w sobie emocjonalną bezpośredniość melodramatu z jednej strony i błyskotliwość komedii z drugiej. Jednocześnie dają widzom poczucie bliskości i autentyczności, jakiego nie potrafiłaby zapewnić żadna forma fabularna ${ }^{5}$.

${ }^{3}$ Zob. na przykład Andreas Huyssen, The Politics of Identification: Holocaust and West Germany, „New German Critique” 1980, nr 19, s. 117-136.

${ }^{4}$ Natan Sznaider, David Levy, Holocaust and Memory in the Global Age, Philadelphia: Temple University Press, 2006, s. 157. Zob. też eidem, Memory Unbound. The Holocaust and the Formation of Cosmopolitan Memory, „European Journal of Social Theory” 2002, t. 5, nr 1, s. 87-106.

${ }^{5}$ Brian G. Rose, The talk show [w:] TV Genres: A Handbook and Reference Guide, red. Brian G. Rose, Westport, CT: Greenwood Press, 1992, s. 329-352, tutaj s. 329; Wie- 
Siłą talk-show jest spontaniczność i uchwycone autentyczne emocje bohaterów. This Is Your Life! miał pod tym względem swoje wypracowane strategie. Powitawszy gości zebranych w studiu, prowadzący zwykł rozglądać się po widowni, szukając wśród niej znajomych twarzy. W omawianym odcinku Ralph Edwards zwraca uwagę na mniej więcej trzydziestoletnią elegancko ubraną kobietę. Podchodzi i pyta, jak się nazywa. Kobieta dość nieśmiało wymawia swoje nazwisko, dlatego prowadzący dopytuje. Dopiero za drugim razem słyszymy wyraźniej wypowiedziane ze wschodnioeuropejskim akcentem: „Hanna Bloch Kohner”. Prowadzący pyta, z kim przybyła do studia, na co kobieta wskazuje najpierw na puste miejsce obok siebie, tłumacząc, że mąż musiał na chwilę wyjść, po czym przedstawia swojego drugiego towarzysza, rozpoczynającego właśnie karierę aktora Jeffreya Huntera. Kobieta próbuje ukryć uśmiech, zapewne spodziewając się, że wkrótce to Hunter zostanie wywołany na scenę i stanie się gwiazdą programu. Edwards zwraca się do Huntera i pyta, czy ten mógłby odczytać z karty, którą prowadzący trzyma przed sobą, tytuł dzisiejszego programu. Kamera ujmuje te trzy postaci jednocześnie. Pomiędzy Edwardsem i Hunterem jakby w tle uśmiechnięta i wciąż nieco onieśmielona kobieta. Kiedy przyjaciel odczytuje z karty: „Hanno Bloch Kohner, oto Twoja historia!”, oczy Hanny otwierają się szeroko, a twarz sztywnieje. „O, nie! O mój Boże!” - wykrzykuje, po czym chowa twarz w dłoniach. W studiu rozlegają się fanfary, a widownia wita bohaterkę programu brawami.

Podobnie rozpoczynał się każdy odcinek This is Your Life!, „najbardziej łzawego telewizyjnego show” owych czasów, jak w 1956 r. określono program w „Saturday Evening Post”6. Autentyczność pierwszej reakcji bohatera lub bohaterki była tak ważna dla producentów programu, że, jak opowiadają, rezygnowano z opracowanego tematu w momencie, gdy bohater przedwcześnie dowiedział się o „podstępie”. Tylko w wyjątkowych sytuacjach konsultowano się wcześniej z gośćmi. Tak było w wypadku aktorki Lillian Roth, cierpiącej na alkoholizm, czy komika i piosenkarza Eddie'go Cantora, chorego na serce. Hannę potraktowano jednak tak jak bohaterów większości odcinków, a potencjalnie traumatyczny charakter wojennych doświadczeń ocalonej Żydówki nie był najwyraźniej uznany za powód do odstąpienia od zasad programu, jak się stało w przywołanych przypadkach.

Od momentu, kiedy gwiazda pojawiała się na scenie, napięcie było podtrzymywane przez kolejno pojawiających się w studiu dawno niewidzianych bliskich lub inne znaczące osoby z przeszłości. Ralph Edwards deklarował, że głównym celem programu była nie tyle prezentacja życiowych osiąnnięć bohaterów, ile prowokowanie i pokazywanie ich emocji. Producenci programu nie zamierzali darować żadnemu bohaterowi i bacznie pilnowali, żeby każdy na scenie „szlochał, łkał, denerwował się,

sław Godzic, Telewizja i jej gatunki. Po „Wielkim Bracie”, Kraków: Universitas, 2004, s. 41-43.

${ }^{6}$ Dean Jennings, It Makes Him Happy to See You Cry, „Saturday Evening Post”, nr 38, 4 II 1956, s. 19, 52, za: Jeffrey Shandler, While America Watches: Televising the Holocaust, Oxford-New York: Oxford University Press, 1999, s. 35.

${ }^{7}$ www.thisisyourlife.com, dostęp 11 X 2011 r. 
a nawet krzyczał”. Wydaje się, że odcinek z Hanną Bloch Kohner spełnił te wymogi, dostarczając wrażeń i emocji, na które liczyli producenci i widzowie programu.

Talk-show jako gatunek często posiłkuje się sensacją, podejmując tematy dziwne i niezwyczajne. Rozpoczynając opowieść o Hannie Bloch Kohner, prowadzący program też stara się wytworzyć nastrój sensacji i w ten sposób przyciągnąć uwagę widzów. W budowaniu napięcia posługuje się kontrastem: „Patrząc na Ciebie, Hanno - mówi - trudno uwierzyć, że przez siedem lat Twojego wciąż krótkiego życia doświadczyłaś strachu, grozy i tragedii. Wyglądasz jak zwykła amerykańska dziewczyna, która dopiero co ukończyła college, zupełnie nie jak ocalała z okrutnej hitlerowskiej zbrodni...”. Tym zdaniem prowadzący wyjaśnia widzom po raz pierwszy, kim jest bohaterka i dlaczego jej historia zasługuje na opowiedzenie. Ale w tych słowach zawiera się coś więcej. Wydaje się, że są one kulturowym refleksem pierwotnego doznania szoku w momencie zetknięcia się wolnego świata ze światem obozów koncentracyjnych. Takie doświadczenie powraca w zarejestrowanych wspomnieniach amerykańskich żołnierzy obecnych podczas wyzwalania obozów w Europie. To oni byli pierwszymi naocznymi świadkami, którzy obrazy nazistowskich obozów przywieźli ze sobą do Ameryki ${ }^{9}$. Wyzwolenie obozów stało się następnie ważnym punktem odniesienia dla amerykańskiej pamięci Zagłady. Motyw ten otwiera między innymi ekspozycję w United States Holocaust Memorial Museum w Waszyngtonie, gdzie opowieść o Zagładzie rozpoczyna się właśnie fotografią z wyzwolenia z 12 kwietnia 1945 r., na której widzimy generała Eisenhowera $z$ innymi oficerami amerykańskimi zebranych wokół zwłok więźniów obozu Ohrdruf w Niemczech ${ }^{10}$. Przedstawiając widzom bohaterkę programu jako szczęśliwą mieszkankę wolnej Ameryki, po której nikt by się nie spodziewał, że jeszcze kilka lat wcześniej tkwiła w piekle obozów koncentracyjnych, Edwards nawiązuje niejako do tamtego kontrastowego zderzenia ze światem totalitarnego koszmaru. Na obozy spoglądamy zatem z bezpiecznej perspektywy niezachwianej cywilizacji zachodniej, a w wyniku sprawnego operowania sensacją przez prowadzącego historia Hanny nabiera cech niezwykłości.

\section{Trauma i przemoc narracji}

W latach pięćdziesiątych przeszłość żydowskich imigrantów wciąż pozostawała niedomknięta. Jednocześnie także ich przyszłość w kraju, który wybrali na swoją nową ojczyznę, była nieokreślona i raczej należała do sfery aspiracji i nadziei.

${ }^{8}$ Jennings, It Makes Him Happy..., za: Shandler, While America Watches..., s. 35.

${ }^{9}$ Bogata kolekcja wspomnień amerykańskich żołnierzy, którzy uczestniczyli w wyzwalaniu nazistowskich obozów, znajduje się w archiwach US Holocaust Memorial Museum (dalej USHMM) w Waszyngtonie. Na uwagę zasługują między innymi: Capt. Guthrie J. Smith liberation collection, 1945; J. George Mitnick collection, 1945; James Worley collection, 2006; E. Newell, Letter relating to the liberation experiences at Dachau and Landsberg. Zob. też film dokumentalny GIs Remember, reż. Jeff Krulik, VHS, USA 1995.

${ }^{10}$ National Archives and Records Administration, USHMM, \#04649. 
Liminalny status tej nowej grupy mieszkańców Ameryki oddają pojęcia, jakimi ich wówczas określano: uchodźcy, dipisi (ang. Displaced Persons), czy „bezdomni Europy". ${ }^{11}$ Podobnie bohaterka telewizyjnego show z 1953 r. nie występuje jeszcze w programie jako ocalała z Zagłady, w znaczeniu w jakim tego pojęcia zaczęto używać później. Przedstawiając Hannę, prowadzący program Ralph Edwards mówi o niej jako „ocalałej z okrutnej hitlerowskiej zbrodni dokonanej na niemieckich Żydach”. Pojęcie „Holocaust” zakorzeni się w amerykańskiej świadomości zbiorowej trzy dekady później, a europejscy Żydzi dopiero wówczas zaczną być w całości postrzegani jako ta grupa, która w sposób szczególny doświadczyła cierpienia w czasie drugiej wojny światowej. Choć wyświetlany pod koniec lat pięćdziesiątych w amerykańskiej telewizji Night and Fog Alaina Resnais często klasyfikowany jest jako dokumentalny film o Holokauście, słowo Żyd nie pada w nim ani razu. Podobnie Judgment at Nuremberg, sztuka telewizyjna (1959), na podstawie której potem powstał film (1961), wspomina zbrodnie na Żydach raczej marginalnie, wymieniając je wśród innych zbrodni nazistów. Dopiero w latach osiemdziesiątych w amerykańskich programach dokumentalnych i rozrywkowych czy też oficjalnych wystąpieniach ukuje się taki sposób przedstawiania Zagłady, w którym niedoszłe ofiary staną się świadkami historii słuchanymi ze szczególną uwagą i szacunkiem. W latach pięćdziesiątych jednak stanowią raczej przedmiot zainteresowania na zasadzie okazjonalnie poruszanej ciekawostki. This Is Your Life! emituje zatem historię Hanny w społeczny kontekst niewrażliwy jeszcze na historyczny wymiar zagłady $\dot{Z} y-$ dów. Jak zatem w tym okresie braku utrwalonych odniesień kulturowych, gdy sami ocaleni pozostają w zawieszeniu między przeszłością a teraźniejszością czy chęcią mówienia o swoich przeżyciach a potrzebą milczenia, samo dopiero się kształtujące telewizyjne medium radzi sobie $\mathrm{z}$ historią tak nieodległą i wciąż nieokreśloną?

Telewizyjna opowieść o Hannie rozpoczyna się w latach trzydziestych, latach szkolnych spędzonych w Teplitz (czes. Teplice, pol. Cieplice) w Czechosłowacji. Na ekranie widzimy zdjęcia miejscowości. Pierwszy gość-niespodzianka w studiu to Frank Lieben, kolega ze szkoły, z którym Hanna ostatni raz widziała się przed wojną. Mężczyzna żwawo wbiega na scenę i wita się z bohaterką programu. Podczas gdy zaskoczona Hanna nie może nacieszyć się widokiem towarzysza z lat szkolnych, wykrzykując raz za razem „Och, jak wspaniale!”, kolega już zaczyna deklamować swoją kwestię - anegdotę o surowym nauczycielu, z którym oboje mieli do czynienia. Prowadzący pyta Liebena, czy on i Hanna byli jedynie przyjaciółmi z klasy, na co mężczyzna odpowiada, że to nie on, ale Walter Kohner, obecny mąż Hanny, zaprzątał już wtedy jej myśli. Hanna rumieni się i uśmiecha zawstydzona, jakby jeszcze raz przeżywała tamte chwile. Frank Lieben występuje tu nie tylko jako przyjaciel z dzieciństwa, lecz pojawia się także, by wprowadzić nas w to, co najbardziej niezwykłe w całej historii, jak program zdaje się sugerować: wątek miłości, która zaczęła się we wczesnej młodości i która po latach rozłąki i ciężkich przeżyć została ponownie odnaleziona i sprowadziła Hannę do Ameryki.

\footnotetext{
${ }^{11}$ Shandler, While America Watches..., s. 27.
} 
Romantyczna miłość oraz imigracja do Stanów Zjednoczonych to dwa motywy, które strukturyzują telewizyjną opowieść o Hannie.

Kolejny rozdział biografii Hanny to jej przeżycia z czasów okupacji niemieckiej i drugiej wojny światowej. Uderzenia w bębny i posępne dźwięki muzyki sygnalizują zmianę nastroju, a na ekranie widzimy archiwalne zdjęcia z wkroczenia wojsk niemieckich do Czechosłowacji. Przez obraz przebija twarz Hanny, teraz już poważna i napięta. Prowadzący zwraca się do bohaterki programu: „Hanno, czy widziałaś wejście wojsk do twojego miasteczka?”. Hanna, jeszcze przed chwilą roześmiana po spotkaniu z przyjacielem, teraz już poważnie odpowiada, że nie i nerwowo poprawiając fryzurę, dodaje, iż musiał to być okropny widok. Kiedy jednak po chwili Edwards wspomni imię męża Hanny, Waltera, i perypetie ze staraniem się o amerykańskie wizy dla obojga, oczy Hanny znowu zaczynają błyszczeć. Ostatecznie jedynie Walterowi udało się zdobyć wizę i oboje zdecydowali, że pojedzie do Ameryki sam, by wkrótce przysłać po Hannę. Był to rok 1938. W tym roku się rozstają i, jak się okaże, ponownie zobaczą się dopiero po wojnie. Walter długo próbował sprowadzić Hannę do siebie, ale ze względu na ówczesną restrykcyjną politykę imigracyjną Stanów Zjednoczonych jego wysiłki okazały się bezskuteczne. W programie jednak w tym kontekście wspomniane zostają tylko enigmatycznie brzmiące „trudności biurokratyczne”, z jakimi para się zetknęła ${ }^{12}$.

Prowadzący pyta Hannę, co się z nią działo dalej. Bohaterka odpowiada, że zdecydowała się wyjechać do rodziny w Amsterdamie, gdzie miała pracować jako gosposia. Ale okazało się, że była kiepską pomocą domową - śmieje się - nie umiała gotować ani sprzątać. Edwards podpowiada, że Hanna podejmowała też inne prace, jako sprzedawczyni w księgarni czy pokojówka w hotelu. W ten sposób wspólnie rekonstruują jej pobyt w Amsterdamie, za co Hanna nagradza gospodarza kokieteryjnym: „Och, ty naprawdę wszystko wiesz!”. Następnie narratorem jest już on sam. Opowiada historię Hanny w drugiej osobie, rozluźniony, podpierając się jedną ręką o poręcz kanapy, na której siedzi bohaterka. „To wszystko działo się przed 10 maja 1940 r. Tego dnia naziści najechali na Holandię, kładąc kres wszelkim nadziejom, że wydostaniesz się z Europy”. Najazd Trzeciej Rzeszy ilustruje mapka, a nastroju grozy dodaje gwałtowna muzyka. „Pozostawiona sama sobie, odcięta od świata i pozbawiona czyjegokolwiek wsparcia - kontynuuje dramatycznym tonem - decydujesz się poślubić nowo poznanego niemieckiego uchodźcę, Karla Benjamina”. Słyszymy już rzewne dźwięki skrzypiec, a kadr wypełnia znowu poważnieją-

${ }^{12} \mathrm{O}$ problemie moralnej odpowiedzialności Ameryki za Zagładę między innymi ze względu na restrykcyjną politykę imigracyjną stosowaną wobec żydowskich uchodźców z Europy zaczęto dyskutować w Stanach Zjednoczonych dopiero w latach osiemdziesiątych ubiegłego wieku. Zob. w tym kontekście: David S. Wyman, The Abandonment of the Jews: America and the Holocaust, 1941-1945, New York: Pantheon Books, 1984 (wyd. polskie: Pozostawieni swemu losowi. Ameryka wobec Holocaustu 1941-1945, tłum. Wacław Sadkowski, Warszawa: PIW, 1994); także: Carl L. Steinhouse, Barred: the Shameful Refusal of FDR's State Department to Save Tens of Thousands of Europe's Jews from Extermination, Bloomington: AuthorHouse, 2007. 
ca twarz bohaterki programu. Kiedy po chwili kamera odjeżdża, ukazując jej całą sylwetkę, widzimy elegancką kobietę usadzoną na wygodnej kanapie, z pochyloną głową, nieco nerwowo obejmującą się rękami. Historię Hanny i Karla znamy ze spisanych przez nią wiele lat później wspomnień ${ }^{13}$. Wkrótce po ślubie zostali schwytani przez gestapo i wywiezieni do obozu w Westerbork. Dzięki pomocy przyjaciół udało im się stamtąd wydostać i wrócić do Amsterdamu, gdzie przez jakiś czas mieszkali jeszcze z rodziną Karla w getcie. Nie na długo jednak, gdyż podczas kolejnego transportu ponownie trafiają do Westerbork. Stamtąd przez Theresienstadt w oddzielnych transportach zostają wywiezieni do Auschwitz. Dopiero po wyzwoleniu w 1945 r. Hanna dowie się, że Karl bezpośrednio z kolejowej rampy został wysłany do komory gazowej. W programie Edwardsa postać Karla pojawia się tylko jako epizod.

Poważny nastrój zostaje na moment przerwany, gdy w studio nagle rozlega się głos przyjaciółki Hanny z obozu Westerbork: „To tam właśnie poznałam Hannę” - słyszymy, a kamera znowu kieruje całą uwagę na Hannę, by pokazać jej reakcję. Ta wygląda na zdezorientowaną. „Spędziłyśmy tam prawie osiem miesięcy - mówi dalej głos - i choć warunki były bardzo ciężkie, okazały się nieporównywalne z obozem, do którego trafiłyśmy później”. Twarz Hanny wreszcie jaśnieje: „Ewa!” - wykrzykuje, rozpoznawszy koleżankę i podrywa się z kanapy, żeby ją przywitać. Groteskowe pomieszanie nastrojów - grozy obozów koncentracyjnych z jednej strony i radości wywołanej ponownym spotkaniem dawno niewidzianej przyjaciółki z drugiej - jest cechą charakterystyczną tego odcinka programu. Regularnie powracający efekt komiczny to wynik postrzeganej z dzisiejszej perspektywy niestosowności, z jaką traktuje się w tym programie temat Zagłady i osobistej tragedii. Przykładem takiego nadużycia jest też sensacyjny ton, jakim Ralph Edwards prowadzi narrację. „Czy rozpoznajesz ten głos, Hanno?” - dopytuje bohaterkę programu. „Należy do kobiety, która była twoją przyjaciółką w czterech obozach koncentracyjnych” - sam sobie odpowiada, wyraźnie akcentując liczbę obozów.

Ze spisanych wspomnień Hanny wiadomo, że kobiety razem przeszły przez obozy w Westerbork, Theresienstadt, Auschwitz i Mauthausen. Widzimy kobietę w wieku mniej więcej naszej bohaterki i podobnej do niej drobnej postury. Uradowana Hanna bierze w objęcia koleżankę: „Och, Ewo, jak wspaniale! Mój Boże, jak oni to wszystko uknuli!”. Ewa wita się serdecznie z Hanną, ale już po chwili zwraca w kierunku prowadzącego i kontynuuje opowieść: „Razem z innymi zostałyśmy załadowane do bydlęcych wagonów i wywiezione do Theresienstadt”. „Niemalże przejeżdżałaś przez rodzinne miasteczko, prawda, Hanno?” - wtrąca Edwards. Hanna na zmianę uśmiecha się i poważnieje, nieco nerwowo, ale też z elegancją komentując: „Tak, ale nie był to przyjemny powrót do domu”. „Jak długo byłyście w tym obozie, Ewo?” - pyta dalej prowadzący. „Tylko parę tygodni” - Ewa przejmuje

${ }^{13}$ Hanna Kohner, Walter Kohner, Frederick Kohner, Hanna and Walter. A Love Story, New York: Random House, 1984. W epilogu wspomniany został występ Hanny w This Is Your Life! z 1953 r. 
z powrotem przekazaną jej pałeczkę narratora: „Następnie zostałyśmy wysłane do obozu zagłady w Auschwitz w Polsce". Tu Hanna obejmuje Ewę, niby to w geście wsparcia, a trochę chyba sama szukając w przyjaciółce schronienia. Ewa subtelnie odpowiada podobnym gestem. Para wtulonych w siebie drobnych kobiet bardzo nieśmiało wypełnia teraz przestrzeń, w której się znajduje.

Należy tu zwrócić uwagę na odmienny status obu kobiet w programie. Choć łączy je wspólna przeszłość, Ewa sama nie występuje jako „ofiara”, lecz pojawia się niejako w roli „świadka” - tu świadka historii Hanny. Pojawia się zatem w studiu w imieniu autorów programu, wygłaszając kwestie wcześniej już przygotowane. Robi to z należną powagą: „Było tam bardzo zimno, a my miałyśmy na sobie tylko cieniutkie sukienki. Dziesięć dziewcząt musiało dzielić ze sobą dwie prycze”. Natomiast Hanna, w przeciwieństwie do zrównoważonej i poważnej Ewy, zachowuje się mniej stosownie, $\mathrm{z}$ trudnością powstrzymując nerwowy śmiech. Kiedy Ewa wspomina o lekkich sukienkach, Hanna wstydliwie zakrywa twarz dłonią, jakby na wspomnienie jakiegoś urwisowskiego wyczynu z młodości. Prowadzący bacznie wpatruje się w bohaterkę: „Każdej z was dano po ręczniku i kawałku mydła, prawda, Hanno?". Lecz kobieta nadal żartuje, pewnie w ten sposób próbując opanować sytuację: „Och, nie pamiętam, żeby tam było mydło”. Prowadzący jednak dalej napiera: „Zostałyście wysłane pod tak zwany prysznic. Nawet ten proceder był jednak bardzo wątpliwy, ponieważ z niektórych pryszniców leciała woda, a z innych gaz, a wy nigdy nie mogłyście być pewne, pod jaki prysznic was skierowano”. Hanna powoli się uspokaja i już pokorniej odpowiada: „Tak, to prawda”. Zdaje się, że dopiero teraz zaczyna poddawać się formule programu. Tonem wszechwiedzącego prowadzący bezlitośnie kontynuuje opowieść, odsłaniając jej szersze dramatyczne tło: „Ty i Ewa miałyście szczęście, ale inni go nie mieli. Wśród nich byli twój ojciec i matka, a także twój mąż, Karl Benjamin. Oni wszyscy stracili życie w Auschwitz”. Na zakończenie tej części opowieści Edwards dziękuje Ewie za przybycie, a ona opuszcza studio przy aplauzie publiczności.

Talk-show Ralpha Edwardsa karmił się nie tyle samą historią, ucieleśnioną przez zapraszanych do studia gości, ile emocjami, które się wiązały z jej rekonstruowaniem. Groza przeszłości odbijająca się na twarzy Hanny w momentach przywoływania informacji o transportach bądź tragicznej śmierci bliskich czy radość bohaterki ze spotkania niewidzianych przez lata przyjaciół stanowią esencję tego programu. O ile jednak autentyczny bohater stanowi rację bytu tego typu talk-show, o tyle granice jego spontaniczności są wyznaczone przez dosyć sztywne ramy scenariusza. Od ruchu scenicznego, gdy rozmowa odbywa się na stojąco bądź gospodarz zaprasza Hannę na kanapę, po czas wyznaczony na poszczególne opowieści, wszystkie elementy programu zdają się precyzyjnie zaplanowane. Dla badacza pamięci najciekawsza jest dynamika między sztywną strukturą programu a tym, co wypełnia jego część spontaniczną: zachowaniem i postawą głównej bohaterki.

Hanna niełatwo poddaje się zaproponowanej formule opowiadania, czując się nieswojo w roli, którą jej narzucono. Wspominanie przeszłości, do jakiego jest 
zmuszana w programie, sprawia jej ból. Jednocześnie broni się przed prezentowaniem jej jako ofiary. Trudne momenty swojej historii wielokrotnie zbywa nerwowym śmiechem bądź żartem na poziomie uczennicy. Kiedy to tylko możliwe, stara się natomiast utrzymać fason eleganckiej pani domu. Serdecznie wita się z gośćmi, niestrudzenie powtarzając uprzejmą formułę: „Och, jak wspaniale”, czy nagradzając prowadzącego kokieteryjnym: „Och, ty już wszystko o mnie wiesz”, za każdym razem, gdy ten dopowiada szczegóły jej osobistej historii. Genderowa i społeczna tożsamość Hanny, młodej imigrantki z Europy o aspiracjach do amerykańskiej klasy średniej, zdaje się górować nad rolą, w jakiej widzieliby ją producenci programu. Nie dysponuje w tym czasie także środkami, by opowiedzieć o sobie jako o ofierze. Tylko raz spotykamy w programie dłuższą wypowiedź bohaterki, relacjonującą moment, kiedy udało jej się nawiązać kontakt z bratem w Auschwitz. Co charakterystyczne, opowiadając tę historię, posługuje się formułą anegdoty opowiadanej na przyjęciu. „Dowiedziałaś się, że twój brat Gottfried także przebywa w Auschwitz, czyż nie, Hanno?” - pyta prowadzący. „Och tak, to było fantastyczne!” - odpowiada jak zwykle z emfazą Hanna. „To było w jego urodziny, 15 października. Moje imię zostało wywołane i staje przede mną lekarz. Wiesz, tam nikt nie ma imion. Tam są tysiące ludzi. Nie znają cię po imieniu. My nawet nie miałyśmy numerów, nie byłyśmy nawet na tyle ważne. No więc stoi przede mną mężczyzna, także więzień. I on po prostu nie mógł uwierzyć, że to jestem ja - że ja jestem siostrą mojego brata - ponieważ wyglądałam naprawdę zupełnie niemożliwie. W każdym razie powiedział mi, że mój brat żyje i jest w tym samym obozie, tylko dosyć daleko ode mnie”. Tu Edwards przerywa Hannie, starając się utrzymać dynamikę tej nieco już przydługiej historii i nie stracić uwagi widzów: „I wysłałaś do niego życzenia urodzinowe?”. „Tak” - kończy Hanna.

Pierwotnym i zasadniczym celem telewizyjnego talk-show jest dostarczenie widzom rozrywki, i to w precyzyjnie określonych godzinach emisji, najlepiej gdy przed telewizorami zbiera się cała rodzina. Ponowne spotkanie w studiu z bratem Friedlem, który po wojnie wyemigrował do Izraela i z którym Hanna nie widziała się od spotkania w obozie, jest punktem kulminacyjnym programu. Narracja o przeżyciach Hanny zostaje tym samym tak skonstruowana, żeby doświadczenie straty i cierpienia było zrównoważone opowieścią o szczęśliwych spotkaniach po latach, romantycznej miłości i szczęściu odnalezionym w Ameryce. W ten rytm wkomponowana jest strata rodziców i byłego męża, którzy zostają tu zaledwie wspomniani. Odnajdujemy także w programie inny stały element gatunku talk-show, mianowicie podsumowanie przez prowadzącego całej historii na zakończenie programu i objaśnienie widzom jej sensu: „Tragiczne przeżycia, jakich doświadczyłaś i których nigdy nie da się zapomnieć, Hanno, zostały złagodzone przez szczęście, które odnalazłaś tutaj, w Ameryce”. Po tych słowach jak w teatrze wszyscy goście pojawiają się jeszcze raz razem w studiu, a widownia nagradza ich brawami. Na ekranie widać jeszcze reklamę linii lotniczych, które sponsorowały podróż brata Hanny do Stanów Zjednoczonych, a sama Hanna zostaje obdarowana biżuterią od nowojorskiego jubilera i luksusową szminką. 
W historii Hanny opowiedzianej widzom This Is Your Life! nie ma miejsca na traumę jako na takie doświadczenie, które nie poddaje się linearnej opowieści i wymyka próbom ujęcia w spójną całość. Pamięć traumatyczna cechuje się fragmentarycznością, zaburzoną koncepcją czasu i brakiem kontekstu sytuacyjnego. W przeciwieństwie do pamięci narracyjnej nie pozwala na świadome odtwarzanie faktów. Kodowana w formie wrażeń i obrazów i w ten sposób przywoływana cechuje się brakiem równoległej narracji werbalnej, co jednocześnie uniemożliwia włączenie jej w ciągłość historii życia. Jest to pamięć kompulsywna i niezależna od woli pamiętającego ${ }^{14}$. Badania pod kierunkiem Marii Orwid prowadzone w Polsce na przełomie lat pięćdziesiątych i sześćdziesiątych ukazały sylwetkę ocalonego bardzo różną od obrazu Hanny kreowanego w programie Ralpha Edwardsa. Traumatyczne doświadczenie stawało się głównym układem odniesienia w życiu codziennym ocalonych, powodując nieufność do ludzi i utrudniając im relacje z bliskimi. Na tzw. KZ-syndrom składają się przewlekłe zmęczenie, zaburzenia snu, koszmary, poczucie zagrożenia, lęk i alienacja ${ }^{15}$.

Ujęcie dręczących wspomnień w ramy narracyjne i włączenie ich w historię całego życia to właśnie główny cel konfrontacji z doświadczeniem traumatycznym. Odbywa się to przez spowiedź, zgodnie z przekonaniem, że otworzenie się, wypowiedzenie i poznanie prawdy ma moc uzdrawiającą. Spowiedź zakłada obecność zarówno mówiącego, jak i słuchającego. Wyznanie osoby, która przeżyła traumatyczne doświadczenie, jest zawsze kierowane do konkretnego słuchacza, który tym samym współtworzy znaczenie, a przez to także staje się współwłaścicielem traumatycznego wspomnienia ${ }^{16}$. W tym sensie można by się zastanawiać, czy publiczność programu This Is Your Life! przysłuchująca się opowieści o Hannie stała się depozytariuszem jej wspomnień, a może nawet stworzyła wspólnotę pamięci. Tak się jednak nie stało, gdyż w czasie tego występu nie mieliśmy do czynienia ze spowiedzią. Historia Hanny opowiedziana została na oczach publiczności w studiu i widzów przed telewizorem, ale to nie Hanna ją napisała i opowiedziała. Nie ona też podjęła decyzję o jej opowiedzeniu. Została zaskoczona przez autorów programu, a także swoich bliskich i bez uprzedzenia wywołana na scenę. Program dawał jedynie złudzenie, że historia ta została opowiedziana na żywo. W rzeczywistości została wcześniej spisana i jedynie wydeklamowana w trakcie programu przez prowadzącego i zapro-

\footnotetext{
${ }^{14}$ Marita Sturken, Narratives of Recovery: Repressed Memories or Cultural Memory [w:] Acts of Memory. Cultural Recall in the Present, red. Jonathan Crewe, Leo Spitzer, HanoverLondon: University Press of New England, 1999, s. 231-248.

${ }^{15}$ Maria Orwid, Socjopsychiatryczne następstwa pobytu w obozie koncentracyjnym Oświęcim-Brzezinka, „Przegląd Lekarski” 1964, t. 20, nr 1, s. 57-68; Antoni Kępiński, KZ-Syndrome, „Archives of Psychiatry and Psychotherapy” 2008, nr 4, s. 77-84.

${ }^{16}$ Dori Laub, Bearing Witness or the Vicissitudes of Listening [w:] Testimony: Crises of Witnessing in Literature, Psychoanalysis, and History, red. Shoshana Felman, Dori Laub, New York: Routledge, 1992, s. 57-92; James E. Young, Holocaust w świadectwach filmowych $i w$ świadectwach video. Dokumentowanie świadka, tłum. Tomasz Łysak, „Literatura na Świecie” 2004, nr 1-2, s. 245-66.
} 
szonych gości. Uczyniono z niej historię ze szczęśliwym zakończeniem, domkniętą: „Koszmar, który trwał 7 lat, kończy się z chwilą, gdy czołgi amerykańskie wjeżdżają i zatrzymują przed bramą obozu" - oznajmia się Hannie. Fragmenty spisanych po latach wspomnień bohaterki pokazują dobitnie, jak opowieść ta mija się z jej doświadczeniem. Dla Hanny i Ewy, przyjaciółki, która wystąpiła w programie, doświadczenie obozów nie skończyło się z chwilą wyzwolenia: „Pewnego popołudnia w Brukseli postanowiłyśmy pójść do kina. Wybrałyśmy film Les enfants du paradis. Film był piękny. Ale w połowie seansu zaczęłyśmy się dziwnie wiercić, nie mogąc dłużej usiedzieć w swoich fotelach. Spojrzałyśmy na siebie w ciemności i razem zgodziłyśmy się, że musimy wyjść. Opuszczając budynek tego pięknego starego kina, czułyśmy się zagubione, jakbyśmy straciły kontakt ze światem”17.

Narracyjna praca wykonana w programie nie jest więc pracą wykonaną przez Hannę. Dzieje się tak zarówno dlatego, że nie pozostawiono jej wiele miejsca na wypowiedź, jak też ze względu na to, że dla samej Hanny było prawdopodobnie jeszcze za wcześnie na opowiedzenie tej historii. Hanna wyraźnie nie odnajduje się w konwencji poruszającej dramatycznej opowieści, do jakiej namawia ją momentami prowadzący program, samozwańczy akuszer jej pamięci. W tym czasie Hanna nie dysponuje też dostępną narracyjną formułą dla świadectwa ocalałej, którą mogłaby się posłużyć. Dlatego opowiadając fragmenty swojej historii, odwołuje się do konwencji anegdoty, tak jak wtedy, gdy opowiada o kontakcie nawiązanym z bratem w Auschwitz.

W epizodzie tym uderzają ponadto eufemizmy i przemilczenia. Hanna wspomina, że więzień-lekarz, który się z nią skontaktował w imieniu brata, nie mógł jej poznać, gdyż wyglądała „zupełnie niemożliwie”. O tym, jak się „wyglądało” w Auschwitz, Hanna opowie, relacjonując to samo wydarzenie w dużo bardziej przejmujący sposób we wspomnieniach spisanych kilkadziesiąt lat później: „[...] w Auschwitz nie można było rozpoznać po wyglądzie czyjegoś wieku. Były tam dwudziestoletnie dziewczyny wyglądające jak zwiędnięte staruszki. [...] Stałam tam, praktycznie naga, bez włosów na głowie i zaczęłam płakać” ${ }^{18}$. Opowiadając w studiu ów epizod, Hanna przemilcza też istotne kwestie. Koncentrując historię wokół wątku urodzin brata, czyni z niej wydarzenie pozytywne, jakby chwilę wytchnienia od koszmaru obozowej codzienności. W rzeczywistości, o czym opowie wiele lat później, oprócz życzeń przekazała bratu informację, że jest w ciąży. Ciąża wiązała się w jej sytuacji $\mathrm{z}$ automatycznym wyrokiem śmierci. Liścik z życzeniami do brata służył jej więc także do przekazania tej ważnej informacji i zwrócenia się o pomoc. Wkrótce brat, zatrudniony w obozowym szpitalu, zorganizował przeniesienie Hanny do baraku szpitalnego, gdzie $\mathrm{w}$ tajemnicy została przeprowadzona aborcja ${ }^{19}$. $\mathrm{Z}$ powodu tego zabiegu Hanna potem przez wiele lat nie mogła mieć dzieci.

${ }^{17}$ Relacja Hanny w: Kohners, Hanna and Walter..., s. 189.

${ }^{18}$ Ibidem, s. 157.

${ }^{19}$ Epizod ten został również opisany we wspomnieniach brata Hanny. Zob. Gottfried R. Bloch, R. Bloch, Unfree Associations. A Psychoanalyst Recollects the Holocaust, Los Angeles: Red Hen Press, 2004 (wyd. 1 1999), s. 165-168. 
Ślady wstydliwej i niewyartykułowanej pamięci odnajdujemy też, gdy Ralph Edwards pyta Hannę o pracę, jaką wykonywała w obozie w Mauthausen. Prowadzący zwraca się do wygodnie usadowionej na kanapie kobiety: „Hanno, do jakiej pracy zostałaś przydzielona w obozie?”. Bohaterka znowu reaguje, chowając twarz w dłoniach i nerwowo śmiejąc się jak nastolatka: „Gdy tam dotarłam, byłam tak chora, że nikt nawet nie chciał mi dać pracy”. Ale prowadzący dopytuje: „Przerzucałaś łopatą węgiel, prawda?”. „Och, cóż...” - reaguje wyraźnym zakłopotaniem Hanna i znowu ucieka w nerwowy śmiech i gest zbywania ręką: „Ależ naprawdę...” „Schudłaś do 33 kilogramów” - Edwards znowu akcentuje na liczbie. „Cóż, naprawdę...” - kontynuuje Hanna. „Z gorączką 39 stopni” - dodaje jeszcze Edwards, a jedyną odpowiedzią Hanny pozostaje „ależ naprawdę...”, aż w pewnym momencie, jakby w poszukiwaniu ostatniej deski ratunku, by odwrócić od siebie uwagę, pokazuje ręką w kierunku kulis i wtrąca: „Ewa też przerzucała węgiel”.

W programie padają gdzieniegdzie sformułowania wskazujące na istnienie już $\mathrm{w}$ tym okresie pewnego kulturowego kodu w opowiadaniu o zbrodniach nazistowskich. Taką wczesną figurą pamięci jest na przykład motyw „wysyłania do gazu” czy tatuowania numerów więźniom Auschwitz. Do figur tych odwołuje się także Hanna. Niemniej znacząca część obozowego doświadczenia Hanny zostaje przez nią w programie przemilczana. W 1953 r. Hanna bądź nie chciała, bądź nie znała jeszcze języka, jakim mogłaby mówić publicznie o głodzie, chorobie, ciężkiej pracy, poniżeniu i lęku, jakich doznała. Te historie są zbyt osobiste, by o nich opowiadać przed kamerami. Należą w tym czasie do sfery wstydliwej intymności, nie są jeszcze doświadczeniami z gatunku przeżyć ocalałej. Jednocześnie telewizja właśnie zaczyna domagać się takiego obnażenia. Jak intruz narusza granice jej prywatności, chcąc uczynić z tych jeszcze niewyartykułowanych doświadczeń historię publiczną. Jest to czas, kiedy owo medium odkrywa potęgę reality show. Nie tylko This Is Your Life! koncentruje się na prywatnych historiach swoich bohaterów, także inne amerykańskie programy telewizyjne powoli wkraczają w sferę prywatności, pozwalając, by ich widzowie przeistoczyli się w podglądaczy.

\section{Oprah Winfrey jedzie do Auschwitz}

Ponad pół wieku później, już w zupełnie innym kontekście kulturowym, ocalały wystąpi w innym popularnym programie, również należącym do klasyki gatunku, Oprah Winfrey Show ${ }^{20}$. Ocalałym natomiast jest Elie Wiesel. Formuła tego odcinka jest inna niż pozostałych odcinków show, ponieważ wyjątkowo rozmowa między gospodynią programu a gościem nie odbywa się w studiu. Oprah razem z ocalałym wybiera się w długą podróż do Europy Wschodniej, do obozu-muzeum Auschwitz-Birkenau. Program rozpoczyna się przed bramą obozową w Brzezince. Stojąca na śniegu Oprah swoim charakterystycznym miękkim głosem rozpoczyna opowieść: „Jestem tutaj, w Polsce, w obozie śmierci Auschwitz, gdzie, jak się ocenia, zginęło

${ }^{20}$ Oprah Winfrey Show, telewizja CBS, styczeń 2006. 
w Holokauście od 1,1 do 1,5 mln ludzi. Większość z nich stanowili wschodnioeuropejscy Żydzi. To tu właśnie, po tych torach, torach kolejowych prowadzących do obozu, wjechał w 1944 r. w bydlęcym wagonie młody chłopak wraz ze swoją rodziną, przyjaciółmi i sąsiadami. Ten młody chłopiec, Elie Wiesel, przeżył, by dać świadectwo zła, do jakiego zdolny jest człowiek”.

W programie This Is Your Life! historia Hanny Bloch Kohner pokazana została jako historia jednostkowa. Ewa czy brat Hanny, którzy również byli ocalałymi z obozów, pojawili się w programie jedynie w charakterze świadków. Historia Elie Wiesela jest już traktowana jako emblematyczna dla doświadczenia europejskich Żydów. Oprah Winfrey nie mówi już o „nazistowskich zbrodniach”, ale o Holokauście. We wstępie prowadzącej mamy do czynienia z dwoma rodzajami uniwersalizacji sensu historii ocalałego. Jedną jest właśnie Zagłada: Elie Wiesel cierpiał jako jeden z milionów europejskich Żydów. Druga to ogólnoludzkie znaczenie tej historii.

Nie jest to jednak wyłącznie kolejna historia Holokaustu, wydarzenia rozpoznawanego już powszechnie przez telewidza XXI w. Oprah Winfrey Show chce uczynić tę historię bliższą widzowi, bardziej namacalną: to wszystko wydarzyło się „tu”, „tymi torami”, pokazuje prowadząca, wjechał transport, w którym był Elie Wiesel. W autentycznym otoczeniu, wśród obozowych baraków, wieży strażniczych i drutów kolczastych, za chwilę widz zobaczy głównego bohatera programu, który w dodatku oświadczy, że nie przyjechałby tu z nikim innym i nie zamierza tu też więcej wrócić. W odróżnieniu od This Is Your Life! z 1953 r., w tym programie już nie tylko bohater, lecz także miejsce mają zapewniać widzom poczucie obcowania z żywą historią.

Niemniej przeniesienie akcji z telewizyjnego studia w historyczną scenerię obozu nie służy jedynie stworzeniu wrażenia autentyczności. Zmiana ta ma też inny istotny wymiar. Naruszone zostały mianowicie formalne ramy programu, które dostosowano do charakteru podejmowanej w odcinku tematyki. W show Ralpha Edwardsa formalne ramy programu były bardzo sztywne. Ustalony porządek opowiadania i przestrzeń telewizyjnego studia wyraźnie krępowały bohaterkę, narzucając jej rolę, w której nie czuła się dobrze. W programie Oprah Winfrey to gość programu wyznacza sposób opowiadania historii. Wiesel stał się przez lata nie tylko symbolem pamięci Holokaustu w Stanach Zjednoczonych, lecz także medialną ikoną, by nie powiedzieć telewizyjnym celebrytą. Tego statusu nie miała bohaterka This Is Your Life!, która wystąpiła w programie jako osoba nieznana publicznie. W programie Oprah rozmowa nie przebiega już według scenariusza pytań, rytm narracji narzuca Elie Wiesel. Prowadząca tylko gdzieniegdzie dopytuje byłego więźnia bądź mu przytakuje, dając mu do zrozumienia, że jest uważnie słuchany. Gdy kroczy z Oprah pod rękę wśród przykrytych częściowo śniegiem obozowych baraków, ciężko oddychając na zimnie, Wiesel dramatycznym tonem zastanawia się na głos: „Wciąż tego nie pojmuję. Musi być jakieś znaczenie tego wszystkiego. Ale co to znaczy? Że zło może triumfować? To wiedzieliśmy. Że można poniżyć człowieka? To wiedzieliśmy. Ale to! To skandal na poziomie samego Stworzenia”. Wiesel ubiera opowieść w swoją własną, specyficzną dla niego retorykę. Wyznania te mają 
charakter przede wszystkim refleksyjny, ich celem nie jest już rekonstrukcja historii ocalałego.

Szczególna retoryka tożsamościowa, która zaczęła być obecna w kulturze zachodniej od lat osiemdziesiątych XX w., przyznała ofiarom historycznych prześladowań specjalny status, idealizując przy tym obraz ocalałych jako postaci pełnych godności i o niepodważalnym autorytecie moralnym. Wystąpienie Elie Wiesela i to, jak się do niego odnoszono w programie Oprah Winfrey, jest przykładem nabożnego szacunku, z jakim we współczesnej kulturze amerykańskiej traktowane są słowa ocalałego. W porównaniu z odcinkiem This Is Your Life!, w którym wystąpiła Hanna Bloch Kohner, odcinek programu Oprah Winfrey nagrywany w Auschwitz pokazuje także nowe rozumienie zagłady Żydów. Holokaust stał się rozpoznawalnym pojęciem opisującym historyczną zbrodnię o unikatowym charakterze, którego nie sposób zrozumieć i ubrać w ramy tradycyjnej opowieści. W roku 2006 ta interpretacja zdaje się oczywista nawet dla producentów Oprah Winfrey Show. Sam moment podsumowania, do jakiego zobowiązana jest na zakończenie prowadząca talk-show, przychodzi jej w tym odcinku z trudem. Przejmując retorykę stosowaną przez jej gościa, wypowiada z przejęciem: „Wiesz, staram się wydobyć z tego wszystkiego sens, ale się nie da. Opowiedzenie tego sprawia, że to wszystko staje się bardziej prawdziwe, ale naprawdę nie potrafię tego objąć myślami”.

Choć Oprah nie może Holokaustu „objąć myślami”, to podróż do Auschwitz ma jednak dla niej głęboki sens duchowy. Nieco wcześniej w programie deklaruje: „Mam poczucie wspólnoty z duszami tych, którzy tu zginęli, i tych, którzy ocaleli, by nieść świadectwo. Nigdy nie czułam się bardziej człowiekiem”. Wprawdzie w porównaniu z This Is Your Life! relacja między konwencją narracyjną a doświadczeniem ocalałego została w tym programie znacząco przeformułowana, niemniej wciąż odnajdujemy tu elementy stylu charakterystyczne dla tradycyjnego talk-show. Montaż, w którym słowa przeplatają się z milczeniem wypełnionym sentymentalną muzyką, czy zbliżenia na twarze prowadzącej i bohatera programu nadają rzewny i intymny charakter tej opowiedzianej w plenerze historii i utrzymują odcinek w gatunkowych ramach Oprah Winfrey Show.

Relacja między gatunkowymi ramami programu a jego treścią określoną przez osoby głównych bohaterów jest zdecydowanie inna w This Is Your Life! z 1953 r. i Oprah Winfrey Show z roku 2006. Wymagania strukturalne nowego gatunku popularnego widowiska narzucały bohaterce programu Edwardsa bardzo określoną rolę, a potrzeba dostarczenia widzom rozrywki znacząco wpływała na sposób budowania jej historii. W tej narracji powojenny amerykański optymizm wyraźnie triumfował nad tragiczną przeszłością czechosłowackiej imigrantki. Również zestawienie opowieści o życiu Hanny, skonstruowanej na potrzeby programu, z jej wspomnieniami wydanymi w latach osiemdziesiątych ubiegłego wieku narzuca interpretację sugerującą pewien brak wrażliwości czy wręcz nadużycie osobistej tragedii bohaterki dla potrzeb rozrywki. Trzeba jednak uwzględnić i to, że konstrukcja tych wspomnień była też w pewnym przynajmniej stopniu uwarunkowana kulturowo 
przez głębokie zmiany społecznego obrazu Holokaustu, które zaszły w Ameryce od lat pięćdziesiątych. W programie Edwardsa przeżyciom ocalałej z obozów koncentracyjnych nadaje się aurę niezwykłości. Nie znajdujemy w nim jednak przejawów refleksji nad wyjątkowym charakterem tych doświadczeń, w tym nad formą i możliwością ich opowiedzenia, w sensie, w jakim o wyjątkowości zagłady Żydów mówi się dzisiaj. Kulturowe ramy pamięci Holokaustu dominują natomiast nad gatunkowymi ramami programu w Oprah Winfrey Show. Ocalony ma tu szczególny status i wręcz wyłączność na opowiedzenie i interpretację, nie tylko swojej zresztą, historii. Wiesel mówi więc i o Auschwitz, i kondycji naszej cywilizacji po Auschwitz. W przeciwieństwie do nieśmiałej Hanny z programu Edwardsa, której słowa i opowiadanie przychodziły z trudem, ten były więzień jest już mistrzem retoryki. W programie Oprah Winfrey mamy już do czynienia ze zjawiskiem takiej postpamięci, która chętnie i otwarcie wykorzystuje gatunki kultury popularnej.

\title{
Słowa kluczowe
}

reprezentacje Zagłady, mass media, gatunek, talk-show, pamięć, trauma

\begin{abstract}
In the 1950s NBC regularly broadcast This Is Your Life! - a 30-minute talk show. The guests included well-known persons as well as unknown heroes of everyday life. A few times the invited guests were the so-called witnesses to history, including Holocaust survivor Czech Jewess Hanna Bloch Kohner. The episode of This Is Your Life! with Hanna Bloch Kohner is perhaps the first time that the Holocaust was used in a TV entertainment show after the war. The structural requirements of a new popular show genre forced the heroine to play a highly specific role, and the need to provide entertainment to the viewers significantly influenced the construction of her story. In that narration post-war American optimism clearly triumphed over the dramatic past of the European Jewish immigrant. This Is Your Life! broadcast Hanna's story into a social context still insensitive to the historical dimension of the Holocaust. Hence, how does the not yet developed medium deal with such close and still unspecified history in the period of no fixed cultural references? To answer this question the author refers to the theory of collective memory and the notion of trauma on the one hand and to the theory of TV genres on the other.
\end{abstract}

\section{Key words}

Holocaust representations, mass media, genre, talk show, memory, trauma 